\begin{tabular}{|c} 
Ambiente \& Água - An Interdisciplinary Journal of Applied Science \\
ISSN 1980-993X - doi:10.4136/1980-993X \\
www.ambi-agua.net \\
E-mail: ambi.agua@gmail.com
\end{tabular}

\title{
Spatio-temporal variability of erosivity in Mato Grosso, Brazil
}

\author{
ARTICLES doi:10.4136/ambi-agua.2276 \\ Received: 02 May 2018; Accepted: 09 Sep. 2018 \\ Luis Augusto Di Loreto Di Raimo ${ }^{1 *}$; Ricardo Santos Silva Amorim ${ }^{1}$; \\ Eduardo Guimarães Couto'; Rodolfo Luiz Bezerra Nóbrega ${ }^{2}$; \\ Gilmar Nunes Torres ${ }^{1}$; Edwaldo Dias Bocuti'; \\ Cristiana Oliveira Silva Almeida ${ }^{3}$; \\ Rafael Vinicius Rodrigues ${ }^{4}$ \\ ${ }^{1}$ Universidade Federal de Mato Grosso (UFMT), Cuiabá, MT, Brasil \\ Faculdade de Agronomia e Zootecnia (FAAZ). Programa de Pós-Graduação em Agricultura Tropical (PPGAT). \\ E-mail: luis.diloreto@hotmail.com,rsamorim.ufmt@gmail.com, egcouto@gmail.com, \\ gilmaragro@gmail.com, ed.bocuti@hotmail.com \\ ${ }^{2}$ University of Reading, Reading, United Kingdom \\ Department of Geography and Environmental Sciences. E-mail: r.nobrega@ reading.ac.uk \\ ${ }^{3}$ Instituto Nacional de Colonização e Reforma Agrária (Incra), Brasília, DF, Brasil \\ E-mail: kika.df@gmail.com \\ ${ }^{4}$ Universidade Federal de Mato Grosso (UFMT), Cuiabá, MT, Brasil \\ Faculdade de Arquitetura, Engenharia e Tecnologia (FAET). E-mail: rafael.vinicius@live.com \\ *Corresponding author
}

\begin{abstract}
The impact of rainfall on surfaces lacking vegetal cover can dissociate soil particles, thereby initiating the erosion process. This is known as rainfall erosivity and is expressed by the $\mathrm{R}$ factor in the Universal Soil Loss Equation. Agricultural areas often show seasonally erosion susceptibility throughout the year due to oscillations of the soil exposure rate and the vegetation change. Considering that approximately 30 million ha of the Mato Grosso State in Brazil is used for agriculture, this study aimed to predict and map the spatial and temporal variability of its territory. We evaluated the monthly $\left(E I_{30}\right)$ and annual $(\mathrm{R})$ erosivity for 158 rain gauge stations and spatialized the values of $E I_{30}$ and $R$ by the Kriging method. It was observed that $\mathrm{R}$ values ranked as very high in the north, and high and medium-high in the south of Mato Grosso state. The mean value is $8835 \mathrm{MJ} \mathrm{mm} \mathrm{ha}^{-1} \mathrm{~h}^{-1}$ year $^{-1}$, considered high. Ninety-one percent of the annual erosivity was concentrated in the period between October and April, corresponding to the rainy season. The highest $\mathrm{R}$ factor values were found in the macro-regions of the northwest, north, west and medium-north of Mato Grosso State.
\end{abstract}

Keywords: erosion, geostatistics, GIS, soil conservation, USLE.

\section{Variabilidade espacial e temporal da erosividade em Mato Grosso, Brasil}

\section{RESUMO}

O impacto da chuva com a superfície de solos descobertos pode causar a desagregação de partículas e iniciar processos erosivos. Esta capacidade da chuva causar erosão em solos sem cobertura é chamada de erosividade e é expressa como R na Equação Universal de Perda de 
Solo. Áreas utilizadas com agricultura apresentam grau de susceptibilidade variável ao longo do ano, devido as oscilações nas taxas de exposição do solo e mudança da vegetação. Considerando que aproximadamente 30 milhões de hectares de Mato Grosso, no Brasil, são utilizados com agricultura, objetivou-se com o presente estudo estimar e mapear a variabilidade espacial e temporal da erosividade em seu território. Primeiramente, foram estimados valores de erosividade mensal $\left(\mathrm{EI}_{30}\right)$ e anual $(\mathrm{R})$ para 158 estações que, posteriormente, foram espacializados pelo método de krigagem. Observou-se que no estado de Mato Grosso predominam valores muito altos de $\mathrm{R}$ ao norte e altos e médio-altos ao sul. $\mathrm{O}$ valor médio de $\mathrm{R}$ é igual à $8835 \mathrm{MJ} \mathrm{mm} \mathrm{ha} \mathrm{h}^{-1} \mathrm{~h}^{-1} \mathrm{ano}^{-1}$, considerado alto. Noventa e um porcento do $\mathrm{R}$ se concentra no período entre os meses de outubro e abril, correspondente a estação chuvosa. Os maiores valores de $\mathrm{R}$ foram observados nas macrorregiões noroeste, norte, oeste e médio norte do estado de Mato Grosso.

Palavras-chave: erosão, conservação do solo, geoestatística, SIG, USLE.

\section{INTRODUCTION}

Erosivity determines the ability of rainfall to cause erosion in an unprotected soil, and it is represented in the Universal Soil Loss Equation (USLE) by the R factor (Wischmeier and Smith, 1978). This factor represents the cumulated monthly values of EI30 index, which can be computed as the product of total kinetic rainfall energy (EC) and maximum 30-min precipitation intensity (I30), both obtained by using pluviographic data. Due to the necessity of pluviographic data, which is scarce in Brazil, the determination of $E I_{30}$ values by the standard method was considered difficult or unfeasible in many regions for a long time. Many studies addressed this gap by obtaining $E I_{30}$ values from regression equations that use the rainfall coefficient $(R c)$ as an independent variable, which is based purely on pluviometric data (Almeida et al., 2012; Aquino et al., 2012; Oliveira et al., 2012). Certainly, the standard method is the most recommended to obtain erosivity, due to the higher temporal resolution of the pluviographic data. However, in regions with scarcity of pluviographic data, such as Mato Grosso State, one alternative that remains is the use of estimation of erosivity values by regression equations. For some areas of Mato Grosso State, Almeida et al. (2011), Almeida et al. (2012) and Di Raimo et al. (2018) obtained high correlations between erosivity, determined by the standard method, and values of $R c$, indicating the high reliability of the estimates.

It is observed that after the simplification of the procedure of obtaining $\mathrm{R}$ values several studies were developed in Brazil to identify the spatiotemporal distribution of erosivity in different regions of the country (Silva et al., 2010a; Oliveira et al., 2012; Aquino et al., 2012; Viola et al., 2014; Machado et al., 2014; Waltrick et al., 2015; Almeida and Casaroli, 2016). These studies with a low density of pluviographic stations were only possible due to the implementation of regression equations in pluviometric stations of locations with correlated $R c$ coefficients, as performed by Oliveira et al. (2012), Waltrick et al. (2015) and Almeida and Casaroli (2016). However, although Mato Grosso State has extensive agricultural activities concentrated between October and March, when $85 \%$ of the annual precipitation occurs (Marcuzzo et al., 2011a; 2011b), no research has yet provided the spatial variation of $\mathrm{R}$ and spatiotemporal variation of $E I_{30}$ in this region.

Preliminary studies about erosivity in the Mato Grosso were done by Almeida et al. (2011), Almeida et al. (2012) and Di Raimo et al. (2018), who developed equations to estimate $E I_{30}$ values for several sites in Mato Grosso. Nevertheless, this punctual information contributes little to regional planning of tillage practices and soil conservation, given that rainfall, $E I_{30}$ and $R$ values have high spatial and temporal variability. Silva (2004), Oliveira et al. (2013) and Trindade et al. (2016) mapped $\mathrm{R}$ values for the entire Brazilian territory. However, as 
demonstrated by Trindade et al. (2016), more specific and detailed studies on smaller areas, such as State-level, are crucial to identifying accurate erosivity information.

Understanding of the spatial and temporal variability of erosivity in Mato Grosso would enable identification of critical areas and periods, in which the rainfall has a comparatively stronger erosive action. Such information is crucial in the planning of tillage practices and soil conservation because the vegetal cover rate of explored areas in Mato Grosso State change throughout the year, especially those cultivated with soybean, corn and cotton. Thus, this study aimed to estimate the rainfall erosivity and its spatial and temporal variability in the entire state of Mato Grosso.

\section{MATERIAL AND METHODS}

The pluviometric data used to undertake this study were obtained from the Hydrological Information System of the National Water Agency (ANA, 2017). In our study, 148 pluviometric stations with a minimum of 10 years of continuous data were selected (Figure 1).

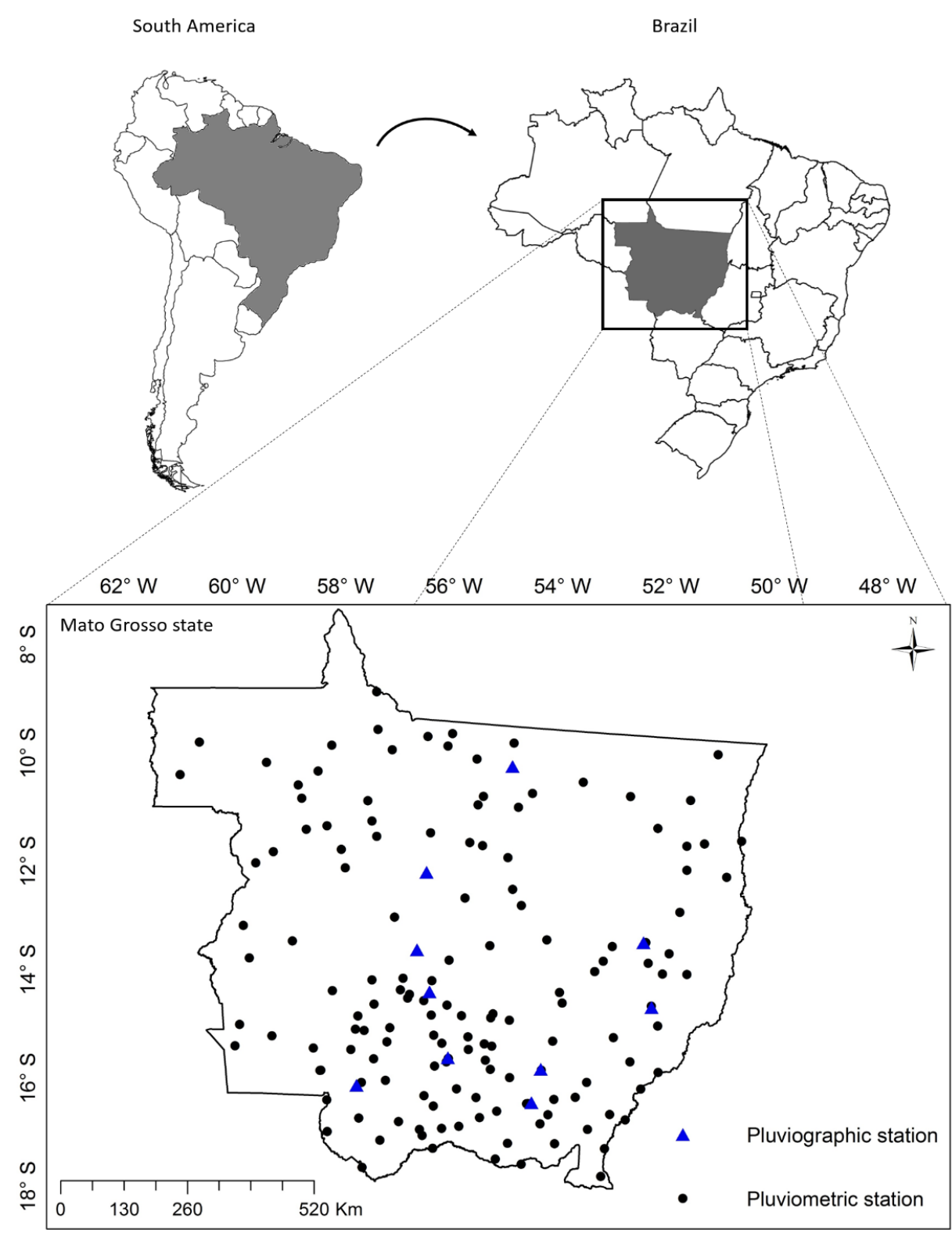

Figure 1. Distribution of the 148 pluviometric stations and the 10 pluviographic stations used. 
For the calculation of the $E I_{30}$ coefficient, equations developed by Almeida (2009) were used. These equations allowed the estimation of the $E I_{30}$ value from the rainfall coefficient $(R c)$ for 10 pluviographic stations in Mato Grosso State (Table 1, Figure 1). The R values were computed from the sum of the monthly values of the $E I_{30}$ coefficient. The $R c$ was derived from Equation 1 (Renard and Freimund, 1994), where $p$ is the average monthly precipitation (mm), and $P$ is the average annual precipitation $(\mathrm{mm})$.

$$
R c=\frac{p^{2}}{P}
$$

Table 1. Regression equations used to estimate monthly erosivity $\left(E I_{30}\right)$ index from the rainfall coefficient $(R c)$ of the respective stations and municipalities of Mato Grosso State (Almeida 2009).

\begin{tabular}{lccc}
\hline Station & County & Equation & $\mathbf{R}^{\mathbf{2}}$ \\
\hline Cáceres & Cáceres & $E I_{30}=135.43\left(R c^{0.538}\right)$ & 0.78 \\
Canarana & Canarana & $E I_{30}=121.18\left(R c^{0.622}\right)$ & 0.87 \\
Cuiabá & Cuiabá & $E I_{30}=244.47\left(R c^{0.508}\right)$ & 0.67 \\
Diamantino & Diamantino & $E I_{30}=51.46\left(R c^{0.883}\right)$ & 0.96 \\
Gleba Celeste & Diamantino & $E I_{30}=171.29\left(R c^{0.605}\right)$ & 0.84 \\
Matupá & Guarantã do Norte & $E I_{30}=115.72\left(R c^{0.746}\right)$ & 0.99 \\
Nova Xavantina & Nova Xavantina & $E I_{30}=96.36\left(R c^{0.517}\right)$ & 0.95 \\
Poxoréu & Poxoréu & $E I_{30}=156.38\left(R c^{0.552}\right)$ & 0.60 \\
Rondonópolis & Rondonópolis & $E I_{30}=167.16\left(R c^{0.567}\right)$ & 0.77 \\
São José do Rio Claro & São José do Rio Claro & $E I_{30}=126.76\left(R c^{0.464}\right)$ & 0.72 \\
\hline
\end{tabular}

To estimate the $E I_{30}$ values, one equation in Table 1 was selected for each of the 148 pluviometric stations. The criteria used to select the equations were adapted from Oliveira et al. (2012). We correlated rainfall characteristics (mean daily precipitation, mean monthly precipitation, mean annual precipitation, precipitated monthly volume, mean monthly Rc and cumulative monthly $\mathrm{Rc}$ ) of the 10 available pluviographic stations with the same rainfall characteristics of the 148 pluviometric stations. The different locations were considered similar when the linear correlation value was equal to or greater than 0.95 . When more than one pluviometric station had a correlation equal or greater than 0.95 with one of the pluviographic stations, the closest among them was considered. Although the standard method for determining erosivity is that proposed by Wischmeier and Smith (1978), regions with scarce rainfall information can be mapped using regression equations to estimate erosivity, as observed in Silva et al. (2010a), Oliveira et al. (2012), Aquino et al. (2012), Viola et al. (2014), Machado et al. (2014), Waltrick et al. (2015) and Almeida and Casaroli (2016).

After defining the equations and the $R c$ values, their respective $E I_{30}$ and $\mathrm{R}$ values were estimated. The spatial variability characterization of the $E I_{30}$ and $\mathrm{R}$ values was conducted using geostatistical techniques. To choose a semivariogram model most appropriate for each situation, the following parameters were analyzed: nugget effect $\left(C_{0}\right)$, sill $\left(C_{0}+C_{1}\right)$, determination coefficient $\left(\mathrm{R}^{2} \mathrm{~s}\right)$, spatial dependence degree (SDD) and range.

SDD was calculated using Equation 2 and classified, according to Cambardella et al. (1994), into three categories: $\leq 25 \%$ as strong spatial dependence; $25 \% \leq$ SDD $\leq 75 \%$ as moderate spatial dependence; and $\geq 75 \%$ as weak spatial dependence. To evaluate the performance of the models in the cross-validation, their respective determination coefficient $\left(\mathrm{R}^{2} \mathrm{cv}\right)$ was analyzed.

$S D D=\frac{C_{0}}{C_{0}+C_{1}} \times 100$ 
After the adjustment of the semivariogram models and the spatial dependence evaluation, the spatial variability of the $E I_{30}$ and R factor was mapped for Mato Grosso State by the ordinary Kriging technique (Behera et al., 2018). Such technique was used because it is more reliable than the other methods (Meul and Meirvenne, 2003), including for specialization of erosivity (Mello et al., 2015), and because this is the best predictor to obtain values at unsampled locations and in conditions with sparse and random sampling (Behera et al., 2018). The $E I_{30}$ and $\mathrm{R}$ factor values of the created maps were classified as shown in Table 2.

The $\mathrm{R}$ values were correlated with latitude, longitude and elevation, aiming for the best comprehension of erosivity spatial variability within Mato Grosso State. In order to argue about the peculiarities, critical situations and regionally isolated events, the $E I_{30}$ and $\mathrm{R}$ maps were presented with the identification of macro-regions of agro economic similarity (northwest, north, northeast, middle-north, west, south-center and southeast), as established by the Mato Grosso Institute of Agriculture Economics (IMEA, 2010).

Table 2. The categories for interpretation of the $\mathrm{R}$ and $E I_{30}$ index.

\begin{tabular}{|c|c|c|}
\hline \multirow{6}{*}{$\begin{array}{c}\text { R categories } \\
\text { according to Oliveira et al. (2013) }\end{array}$} & Erosivity Category & R (MJ mm ha' ${ }^{-1} h^{-1}$ year $\left.^{-1}\right)$ \\
\hline & Low & $\mathrm{R} \leq 2452$ \\
\hline & Medium & $2452<\mathrm{R} \leq 4905$ \\
\hline & Medium-high & $4904<\mathrm{R} \leq 7357$ \\
\hline & High & $7357<\mathrm{R} \leq 9810$ \\
\hline & Very High & $\mathrm{R}>9810$ \\
\hline \multirow{6}{*}{$\begin{array}{c}\boldsymbol{E I}_{\mathbf{3 0}} \text { categories } \\
\text { according to Carvalho (2008) }\end{array}$} & Erosivity Category & $E I_{30}\left(\mathrm{MJ} \mathrm{mm} \mathrm{ha}{ }^{-1} h^{-1}\right.$ month $\left.^{-1}\right)$ \\
\hline & Very Low & $<250$ \\
\hline & Low & $250<\mathrm{R} \leq 500$ \\
\hline & Medium & $500<\mathrm{R} \leq 750$ \\
\hline & High & $750<\mathrm{R} \leq 1000$ \\
\hline & Very High & $\mathrm{R}>1000$ \\
\hline
\end{tabular}

\section{RESULTS AND DISCUSSION}

The distinctness between dry and wet/rainy season is reflected by the $E I_{30}$ values for the different months of the year (Figure 2). The period from October to April corresponds to 91\% of the annual erosivity. From May to September, the period with the lowest rainfall rates, the $E I_{30}$ values contributed to only $9 \%$ of the annual erosivity.

Table 3 provides the parameters of the semivariogram used in the spatial dependence analysis and the reliability of the spatial characterization of the $E I_{30}$ and $\mathrm{R}$ factor in Mato Grosso State. The SDD values indicated that the spatial dependence of the regionalized variables is strong $(<25 \%)$ for nine months of the year (Cambardella et al., 1994). The semivariograms of May, June and July were the only ones that did not present a strong spatial dependence category, showing SDD values of 32, 40 and 26\%, respectively, which are categorized as moderate spatial dependence (Cambardella et al., 1994).

The semivariogram for the $\mathrm{R}$ values showed $13 \%$ of the total semivariance was random and framed in the strong spatial dependence category (Cambardella et al., 1994). SDD values determined by Aquino et al. (2012), Viola et al. (2014), Silva et al. (2010b) and Mello et al. (2013) were classified as strong spatial dependence, and accounted for 12, 0, 7, 5 and $0 \%$ of the random variation, respectively. 


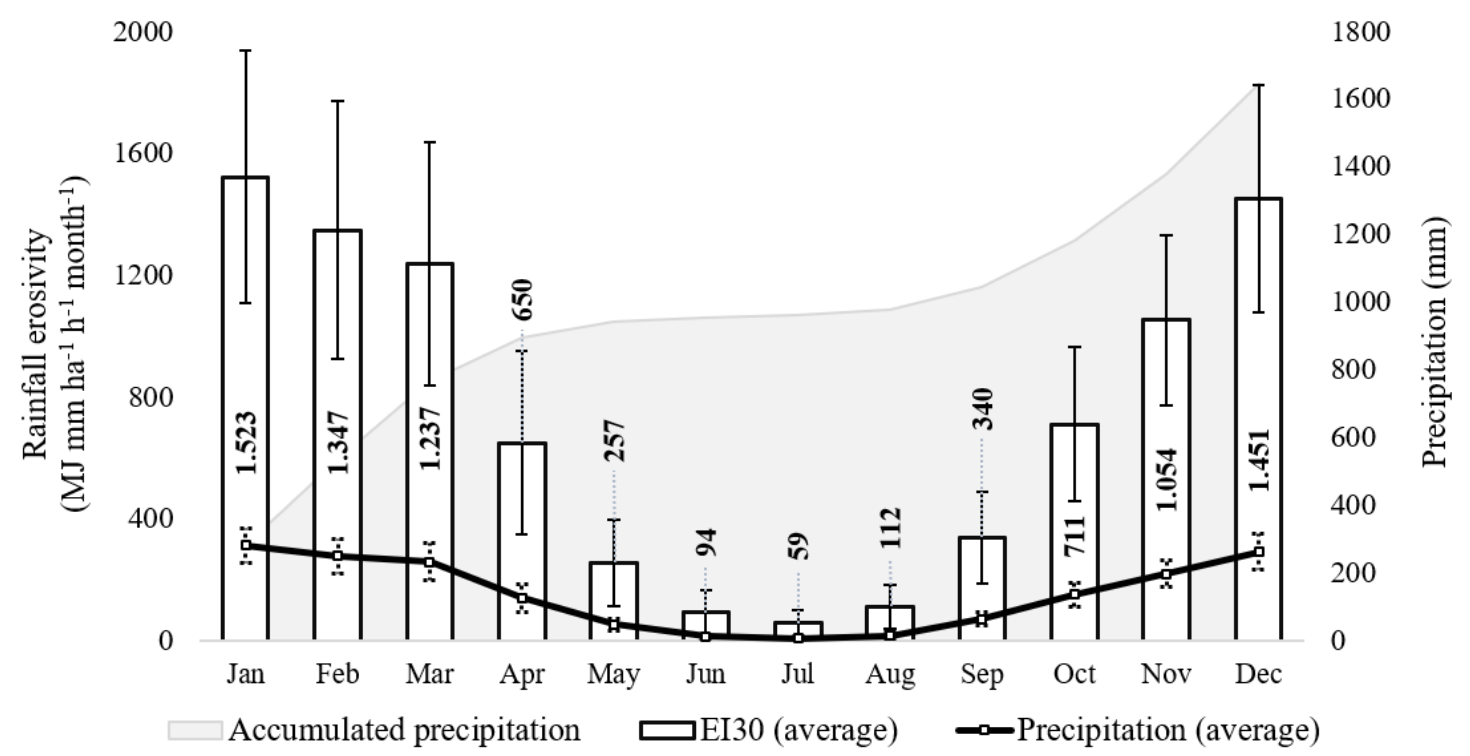

Figure 2. Average monthly and standard deviation of the $E I_{30}$ and the precipitation values of the 158 studied stations in Mato Grosso State.

In all semivariograms, the best parameters were obtained by using an exponential model. Such results endorse the available literature studies, which show that this model presents the best parameters when compared with other models, such as Gaussian and spherical (Mello et al., 2007; Montebeller et al., 2007; Silva et al., 2010b; Viola et al. 2014).

Table 3. Parameters of the semivariograms used to spatialize $E I_{30}$ and $\mathrm{R}$ values in Mato Grosso State.

\begin{tabular}{lcccccc}
\hline \multirow{2}{*}{ Period } & \multicolumn{6}{c}{ Parameters } \\
\cline { 2 - 7 } & $\boldsymbol{C}_{\mathbf{0}}$ & $\boldsymbol{C}_{\mathbf{0}}+\boldsymbol{C}_{\mathbf{1}}$ & $\mathbf{R}^{\mathbf{2}} \mathbf{s}$ & $\mathbf{R}^{\mathbf{2}} \mathbf{c v}$ & $\mathbf{S D D}(\boldsymbol{\%})$ & Range (km) \\
\hline January & 33200 & 277400 & 0.96 & 0.65 & 12 & 1798.2 \\
February & 49000 & 409000 & 0.95 & 0.60 & 12 & 3136.32 \\
March & 17000 & 345000 & 0.82 & 0.70 & 5 & 2669.76 \\
April & 5100 & 221200 & 0.77 & 0.72 & 3 & 2987.28 \\
May & 4759 & 14971 & 0.88 & 0.49 & 32 & 794.88 \\
June & 1225 & 3071 & 0.65 & 0.51 & 40 & 207.36 \\
July & 451 & 1735 & 0.95 & 0.53 & 26 & 719.28 \\
August & 1829 & 11339 & 0.85 & 0.52 & 16 & 2345.76 \\
September & 6009 & 49568 & 0.84 & 0.64 & 12 & 2796.12 \\
October & 16212 & 239850 & 0.77 & 0.66 & 7 & 5280.12 \\
November & 25565 & 209359 & 0.96 & 0.57 & 11 & 5200.2 \\
December & 39394 & 275310 & 0.87 & 0.61 & 14 & 3165.48 \\
\hline Annual & 1456791 & 10836743 & 0.82 & 0.66 & 13 & 2222.64 \\
\hline
\end{tabular}

$\boldsymbol{C}_{\mathbf{0}}$ : nugget effect; $\boldsymbol{C}_{\mathbf{0}}+\boldsymbol{C}_{\mathbf{1}}$ : sill; $\mathbf{R}^{2} \mathbf{s}$ : determination coefficient of semivariogram; $\mathbf{R}^{2} \mathbf{c v}$ : determination coefficient of cross-validation; and SDD: spatial degree dependence. All adjusted semivariograms are exponential.

Figure 3 shows the $E I_{30}$ maps for Mato Grosso, contrasting the seven macro-regions proposed by the IMEA (2010). Overall, when analyzing the discrepancy in the $E I_{30}$ values throughout the months of the year, variations can be seen in the erosivity bands towards northwest-southeast, which is when the rainy season starts, and towards southeast-northwest, which is the rainy-dry transition period (Figure 3). This variability pattern is attributed to the 
influence of the Continental Equatorial Mass (CEM), created from the high evapotranspiration of the Amazon forest, which passes over Mato Grosso and provides territory-wide rainfall events.

The CEM expansion starts in August, leaving the Amazon region towards the Mato Grosso State. This movement appears predominantly in the northwest-southeast direction until reaching São Paulo State. From January, the area of influence of this mass begins to fade in the southeast-northwest direction, finally concentrating only in the original region (Amazon region), where it stays and restricts its influence on the pluviometric pattern (Zavattini, 2009; Gan et al., 2009; Marcuzzo et al., 2012).

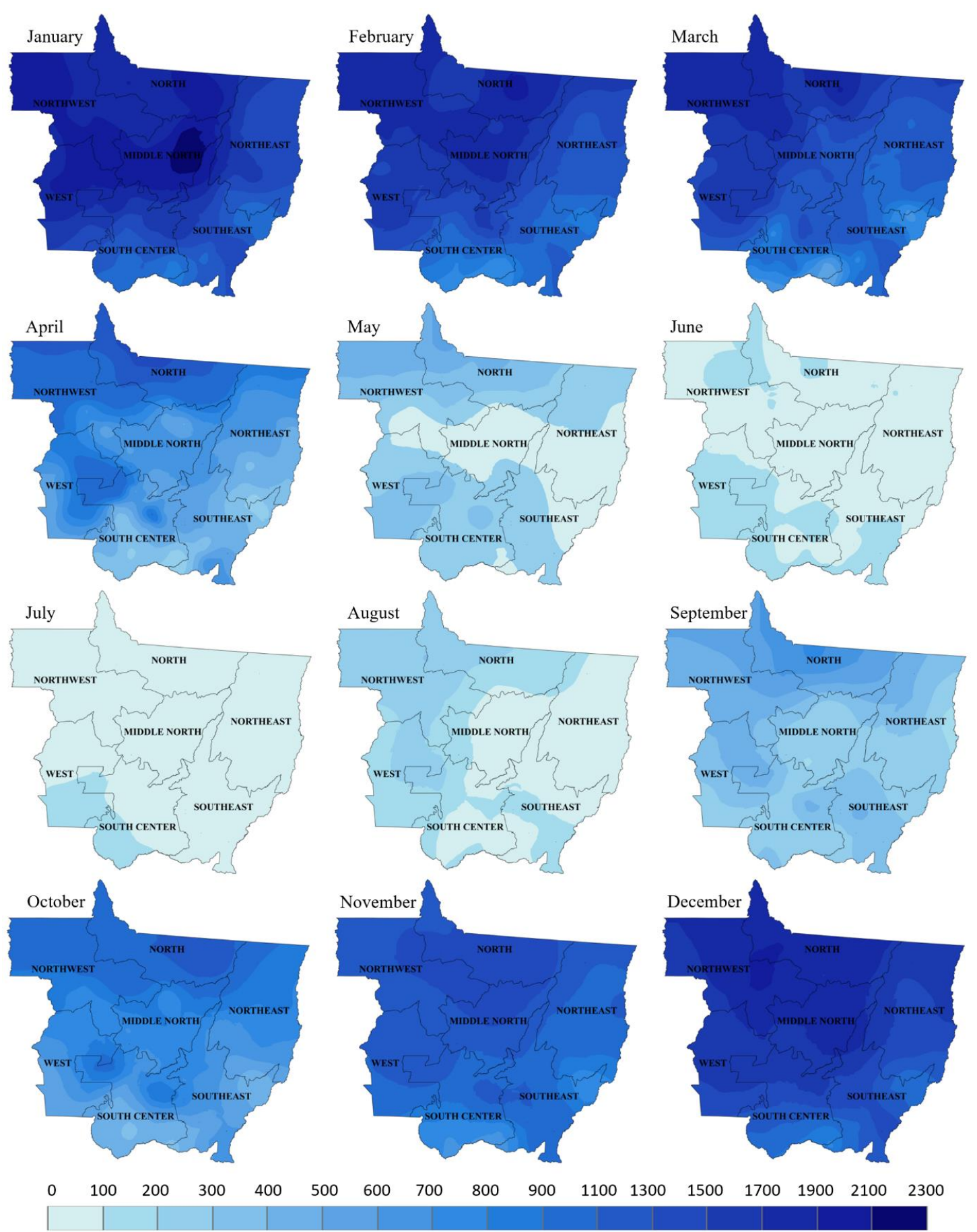

Figure 3. Monthly erosivity maps $\left(E I_{30}\right)$ for Mato Grosso State (MJ mm ha $\left.{ }^{-1} \mathrm{~h}^{-1} \mathrm{month}^{-1}\right)$.

\section{IPABH}


It is possible to note that Mato Grosso State presents different $E I_{30}$ patterns in three distinct periods during the year (Figure 3). The first one is in October and November, related to the beginning of the rainy season, in which the $E I_{30}$ values increase and range between the low and very high categories. The second period, from December to March, is associated with the most precipitation in Mato Grosso, in which the $E I_{30}$ values are predominantly high and very high. The third period, from April to September, corresponding to the driest season in Mato Grosso, when low $E I_{30}$ values occur mostly in the low and very low categories.

During the first and second $\mathrm{EI}_{30}$ periods, many agricultural activities occur in Mato Grosso, causing changes on the soil surface. These are considered the more critical periods, especially from October to February (responsible for 69\% of R), when activities such as tilling, sowing and harvesting are concentrated. In the third period, associated with low erosivity, the majority of the soils are covered by the crop canopy, characterizing the least critical phase. However, activities of soil preparation and invasive plant control during the drought season can cause soil loss, due to the first erosive rainfalls that occur in September (Morais et al., 1991).

As shown in this study, Tocantins (Viola et al., 2014) and Goiás (Almeida and Casaroli, 2016) states were also characterized as having high and very high $E I_{30}$ values between December and March (Period 2), and low and very low $E I_{30}$ values from April to September (Period 3). Such similarity is due to the uniformity of rainfall distribution that is proportionated by the proximity between these states. Such proximity makes the South Atlantic Convergence Zone (SACZ) and the CEM behave with similar intensity above the territory of Mato Grosso, Goiás and Tocantins States (Carvalho and Jones, 2009; Gan et al., 2009).

In the map of R shown in Figure 4, very high category values predominate in the northern region of Mato Grosso and lower $\mathrm{R}$ values in the southern region (the same was observed for the $E I_{30}$ values). However, even the lowest values of $\mathrm{R}$, found in the southern region, are classified as a medium-high category, according to Oliveira et al. (2013). Considering the entire Mato Grosso State, it includes only the three highest categories of the five proposed by this author.

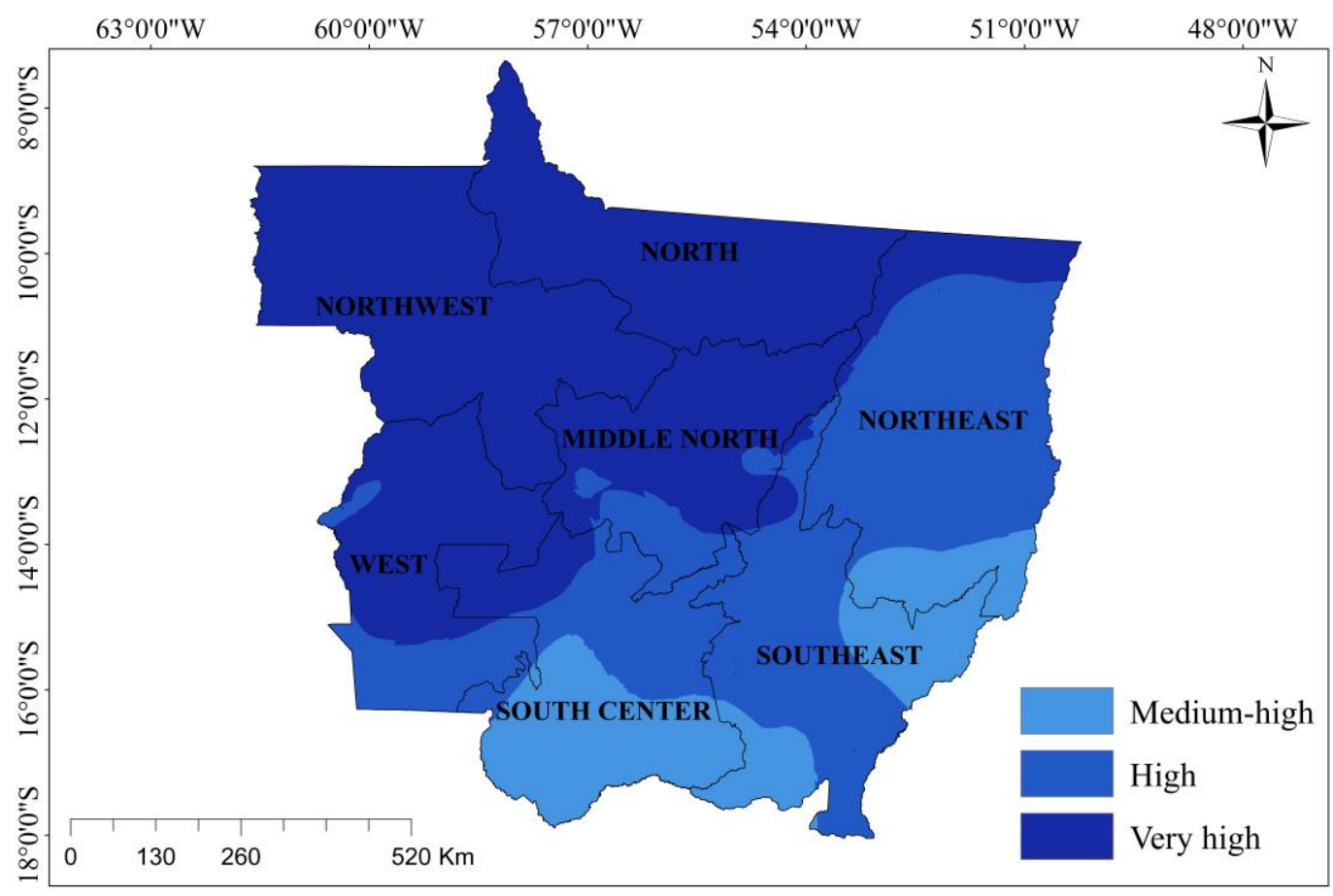

Figure 4. Map of the annual $\mathrm{R}$ for the Mato Grosso State classified according to Oliveira et al. (2013). 
Panagos et al. (2017) mapped world's erosivity and obtained values higher than $5200 \mathrm{MJ}$ $\mathrm{mm} \mathrm{ha} \mathrm{h}^{-1} \mathrm{~h}^{-1}$ year $^{-1}$ (medium-high class or upper) for Mato Grosso State territory, highlighted for regions with values upper than $7400 \mathrm{MJ} \mathrm{mm} \mathrm{ha}^{-1} \mathrm{~h}^{-1}$ year-1 (high or very high classes) at north and northwest. Oliveira et al. (2013) and Trindade et al. (2016) mapped the erosivity of Brazil and got values for Mato Grosso always higher than $6000 \mathrm{MJ} \mathrm{mm} \mathrm{ha}^{-1} \mathrm{~h}^{-1}$ year $^{-1}$ (mediumhigh class or upper), with remarkable increase of erosivity to the north and northeast of the state (between 10000 and $14000 \mathrm{MJ} \mathrm{mm} \mathrm{ha}^{-1} \mathrm{~h}^{-1}$ year ${ }^{-1}$ ), that categorizes such as a very high class. Despite the similar range of erosivity values between the present study and those presented by Oliveira et al. (2013), Trindade et al. (2016) and Panagos et al. (2017), there is a considerable difference in spatial variation of the data, perhaps due to the higher density of information used in this work. Such comparison evidences the importance of erosivity studies that contemplate smaller areas and use greater information density.

The mean $\mathrm{R}$ value observed for Mato Grosso was $8835 \mathrm{MJ} \mathrm{mm} \mathrm{ha} \mathrm{m}^{-1} \mathrm{~h}^{-1} \mathrm{year}^{-1}$, which is classified as high according to Oliveira et al. (2013). The high R values obtained for Mato Grosso are typical of tropical regions and corroborate with those obtained in Minas Gerais (Mello et al., 2007), Mato Grosso do Sul (Oliveira et al., 2012), Tocantins (Viola et al., 2014) and Paraná (Waltrick et al., 2015) Brazilian states.

The $\mathrm{R}$ values attained in tropical regions are typically higher than those in temperate regions. Examples can be observed in the studies done in Switzerland (Meusburger et al., 2012), Italy (Borrelli et al., 2016), Europe (Ballabio et al., 2017) and the global scale (Panagos et al., 2017). In fact, Panagos et al. (2017) mapped the $R$ for all the world and obtained an average value of $7104 \mathrm{MJ}$ and $3729.3 \mathrm{MJ} \mathrm{mm} \mathrm{ha}^{-1} \mathrm{~h}^{-1}$ year $^{-1}$ for the tropical and temperate climate regions, respectively. The high values in tropical regions result from the great amount of convective rainfall (high intensity and high kinetic energy values of the raindrops) when compared with the characteristics of temperate climates (Oliveira et al., 2013; Machado et al., 2014).

All macro-regions of Mato Grosso State have high R values (Figure 4), which highlight the fact that any agricultural activity developed there requires the adoption of conservation practices. However, the most critical values occur in the northwest, north, west and middlenorth macro-regions. The northwest and north macro-regions are dominated by areas with native forests and pastures, which are considered effective cover for soil protection (Da Cunha et al., 2017). Unlike the northwest and north macro-regions, the middle-north and west contain large areas of agricultural land and, thus, they are considered the most critical macro-regions. In the middle-north, specifically, in the municipality of Nova Mutum, Sorriso, Lucas do Rio Verde, Nova Ubiratã, Vera, Santa Carmem, Feliz Natal, Cláudia, Paranatinga and União do Sul, which are responsible for a great part of the grain production in Mato Grosso, the highest $E I_{30}$ values have been observed. These values occur in January and correspond to approximately $2300 \mathrm{MJ} \mathrm{mm} \mathrm{ha}^{-1} \mathrm{~h}^{-1}$ month $^{-1}$ (Figure 3).

The spatialization of $\mathrm{R}$ values in Mato Grosso State (Figure 4) shows the variation of values in the northwest-southeast direction, as similarly observed in the $E I_{30}$ maps (Figure 3). Such characteristic corroborates the results of Silva (2004) and Trindade et al. (2016) that spatialized the $\mathrm{R}$ in Brazil. This variation of values in the northwest-southeast direction occurs due to two factors: the influence of the CEM on the state precipitations (Zavattini, 2009; Gan et al., 2009; Marcuzzo et al., 2012) and the change of vegetation in the northwest-southeast direction, accompanied, in the same direction, by decreasing occurrence of convective rains.

Similarly to the Amazon region, in the northwest of Mato Grosso dense forests predominate, but towards northwest-southeast of Mato Grosso we find the Amazon-Cerrado ecotone and then the Cerrado biome, which is a relatively dry forest with less vegetation density. In the Amazon region, high rates of evapotranspiration and high temperatures occur, which frequently cause convective rainfall (Mello et al., 2013). Due to the decrease of rainforest

\section{IPABH}

Rev. Ambient. Água vol. 13 n. 6, e2276 - Taubaté 2018 
vegetation in the northwest-southeast direction, the frequency of rainfall also reduces and, consequently, the $\mathrm{R}$ values decrease.

The extension of the CEM and the decrease of the denser vegetation towards northwestsoutheast also explain the inverse and significant association between $\mathrm{R}$ and latitude (Figure 5a). The greater capacity of latitude to explain the variations of $R$ in Mato Grosso is justified by the large latitudinal variation, in comparison to longitudinal variation, between Mato Grosso and the Amazon region, considering its strong influence on the pluviometric pattern of this state.
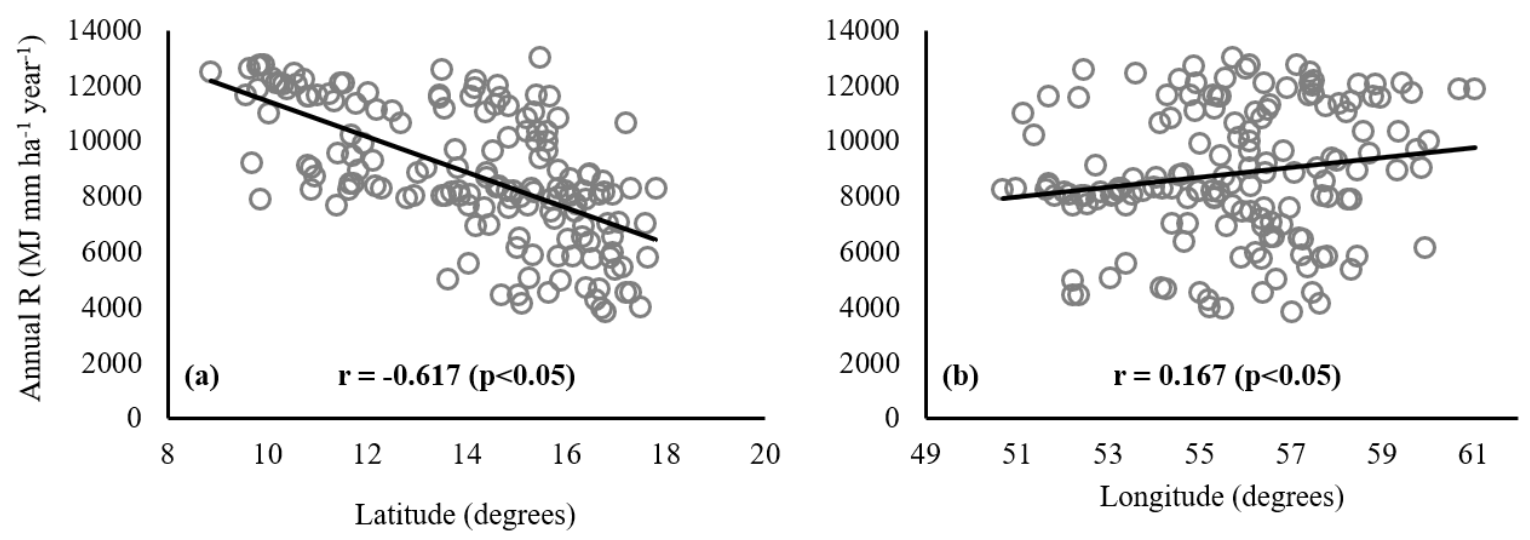

Figure 5. Correlation graphs between $R$ and latitude (a) and longitude (b).

Similar results regarding the variation of the $\mathrm{R}$ values compared to the geographic coordinate variations in the central-west region of Brazil were obtained by Mello et al. (2013). These authors also associated the correlation between $\mathrm{R}$ and latitude with the influence of Amazonian vegetation and its high rainfall rates. In Minas Gerais State, Mello et al. (2007) did not obtain relevant correlation coefficients between the geographic coordinates and the $\mathrm{R}$ values. Despite being also influenced by hot and humid air masses from the Amazon (CEM), the $\mathrm{R}$ value in Minas Gerais is more influenced by the mountains ranges, which effect orographic rainfalls, than by variations in latitude and longitude.

As shown in the Figures $6 a$ and $6 \mathrm{~b}$, the correlation between the $\mathrm{R}$ and elevation values is high and significant only up to $300 \mathrm{~m}$. The greater $\mathrm{R}$ values in high places come from the greater precipitation in these regions, which result from the higher values of accumulated kinetic energy. These results corroborate those obtained by Moreira et al. (2006), who noted reduced $R$ values with the decrease of elevation in São Paulo State.
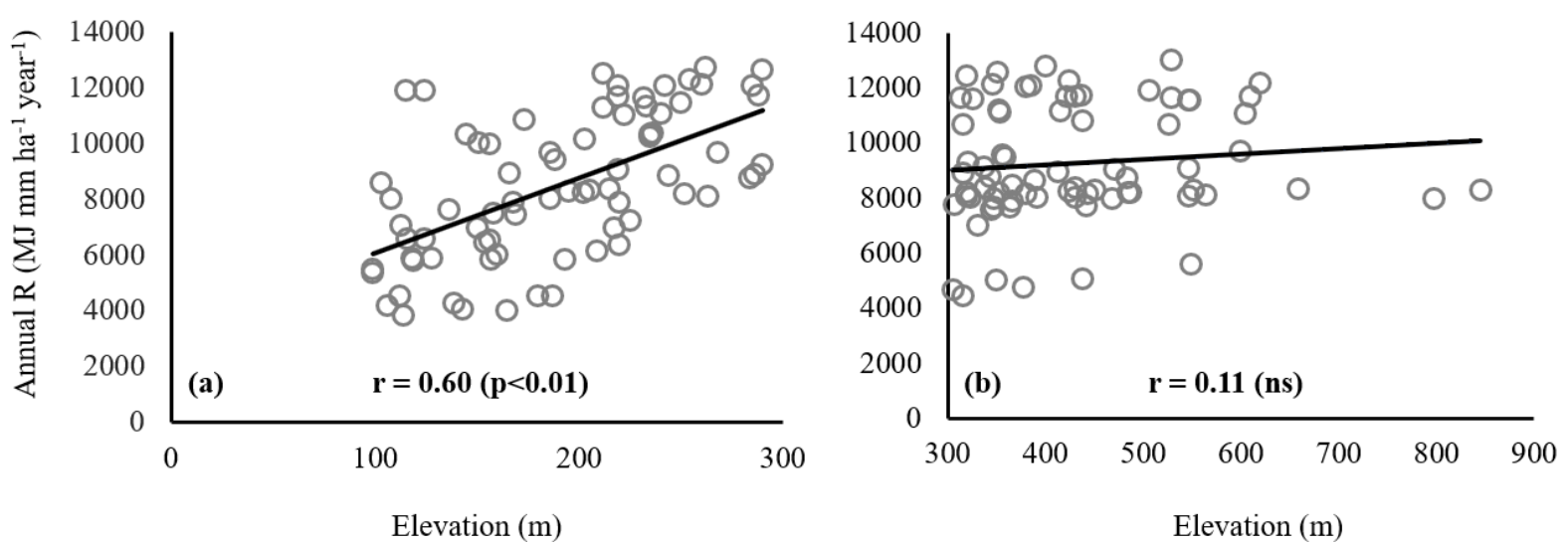

Figure 6. Correlation graph between $\mathrm{R}$ and elevation, from 0 to $300 \mathrm{~m}$ (a) and from 300 to $900 \mathrm{~m}$ (b). 


\section{CONCLUSIONS}

The mean $\mathrm{R}$ value for Mato Grosso is classified as high and equivalent to $8835 \mathrm{MJ} \mathrm{mm} \mathrm{ha}^{-1} \mathrm{~h}^{-1}$ year $^{-1}$.

Ninety-one percent $(91 \%)$ of the total annual of erosivity occurs from October to April in Mato Grosso State.

The period from October to February is considered the most critical in Mato Grosso State, due to the high values of erosivity (responsible for $69 \%$ of $\mathrm{R}$ ) together with the presence of exposed areas during planting and harvesting times.

In Mato Grosso, $\mathrm{R}$ values in the very high category predominate in the northern region and high and very high in the southern region, respectively.

In all macro-regions of Mato Grosso State, there are high $\mathrm{R}$ values. However, the most critical values (very high) are observed in the northwest, north, west and middle-north macroregions.

Besides rainfall, the latitude and elevation, up to $300 \mathrm{~m}$, were the characteristics that best correlated with the spatial variations of $\mathrm{R}$ in the Mato Grosso State.

\section{REFERENCES}

AGÊNCIA NACIONAL DE ÁGUAS - ANA (Brasil). Sistema nacional de informações sobre recursos hídricos. Brasília, 2002.

ALMEIDA, C. O. S. D. Erosividade das chuvas no estado de Mato Grosso. 2009. Dissertação (Mestrado em Ciências Agrárias) - Universidade de Brasília, Brasília, 2009.

ALMEIDA, C. O.; AMORIM R. S.; COUTO, E. G.; ELTZ, F. L.; BORGES L. E. Potencial erosivo da chuva de Cuiabá, MT: Distribuição e correlação com a precipitação pluviométrica. Revista Brasileira de Engenharia Agrícola e Ambiental, v. 15, p. 178184, 2011. http://dx.doi.org/10.1590/S1415-43662011000200011

ALMEIDA, C. O.; AMORIM, R. S.; ELTZ, F. L.; COUTO, E. G.; JORDANI, S. A. Erosividade da chuva em municípios do Mato Grosso: Distribuição sazonal e correlações com dados pluviométricos. Revista Brasileira de Engenharia Agrícola e Ambiental, v. 16, p. 142-152, 2012.

ALMEIDA, R. T. S.; CASAROLI, D. Erosividade média e o calendário agrícola da microrregião sudoeste do estado de Goiás. GeoFocus, Revista Internacional de Ciencia y Tecnología de la Información Geográfica, v. 17, p. 26-43, 2016.

AQUINO, R. F.; SILVA, M. L. N.; FREITAS, D. A. F. D.; CURI, N.; MELLO, C. R. D.; AVANZI, J. C. Spatial variability of the rainfall erosivity in southern region of Minas Gerais State, Brazil. Ciência e Agrotecnologia, v. 36, n. 5, p. 533-542, 2012. http://dx.doi.org/10.1590/S1413-70542012000500006

BALLABIO, C.; BORRELLI, P.; SPINONI, J.; MEUSBURGUER, K.; MICHAELIDES, S.; BEGUERÍA, S. et al. Mapping monthly rainfall erosivity in Europe. Science of the Total $\begin{array}{lllll}\text { Environment, } & \text { v. } & 579, & \text { p. } & 1298-1315,\end{array}$ https://doi.org/10.1016/j.scitotenv.2016.11.123

BEHERA, S. K.; MATHUR, R. K.; SHUKLA, A. K.; SURESH, K.; PRAKASH, C. Spatial variability of soil properties and delineation of soil management zones of oil palm plantations grown in a hot and humid tropical region of southern India. Catena, v. 165, p. 251-259, 2018. https://doi.org/10.1016/j.catena.2018.02.008 
BORRELLI, P.; DIODATO, N.; PANAGOS, P. Rainfall erosivity in Italy: a national scale spatio-temporal assessment. International Journal of Digital Earth, v. 9, n. 9, p. 835850, 2016. https://doi.org/10.1080/17538947.2016.1148203

CAMBARDELLA, C. A.; MOORMAN, T. B.; PARKIN, T. B.; KARLEN, D. L.; NOVAK, J. M.; TURCO, R. F. et al. Field-scale variability of soil properties in central Iowa soils. Soil science society of America journal, v. 58, n. 5, p. 1501-1511, 1994. http://dx.doi.org/10.2136/sssaj1994.03615995005800050033x

CARVALHO, N. O. Hidrossedimentologia prática. São Paulo: Interciência, 2008.

CARVALHO, L. M. V.; JONES, C. Zona de Convergência do Atlântico Sul. In: CAVAlCANTI, I. F. de A. et al. (Orgs.). Tempo e Clima no Brasil. São Paulo: Oficina de Textos, 2009.

DA CUNHA, E. R.; BACANI, V. M.; PANACHUKI, E. Modeling soil erosion using RUSLE and GIS in a watershed occupied by rural settlement in the Brazilian Cerrado. Natural Hazards, v. 85, n. 2, p. 851-868, 2017. https://doi.org/10.1007/s11069-016-2607-3

DI RAIMO, L. A. D. L.; TORRES, G. N.; ALMEIDA, C. O. S.; AMORIM, R. S. S.; COUTO, E. G.; NOBREGA, R. L. B. Rainfall seasonality and erosivity for two agro-industrial regions in Brazil. Scientia Agrária, v. 19, p. 44-56, 2018.

GAN, M.; RODRIGUES, L. R.; RAO, V. B. Monção na américa do sul. In: CAVALCANTI, I. F. de A. et al. (Orgs.). Tempo e Clima no Brasil. São Paulo: Oficina de Textos, 2009.

INSTITUTO MATO-GROSSENSE DE ECONOMIA AGROPECUÁRIA - IMEA, Mapa das $\begin{array}{llll}\text { macrorregiões do } & \text { IMEA. } & \text { Nov. }\end{array}$ http://www.imea.com.br/upload/publicacoes/arquivos/justificativamapa.pdf. Access: 12 Oct. 2016

MACHADO, D. O.; ALVES-SOBRINHO, T.; RIBEIRO, A. D. S.; IDE, C. N.; OLIVEIRA, P. T. S. Erosividade da chuva para o bioma Pantanal. Engenharia Sanitária e Ambiental, v. 19, n. 2, p. 195-201, 2014. http://dx.doi.org/10.1590/S1413-41522014000200010

MARCUZZO, F.; ROCHA, H. M.; MELO, D. Mapeamento da precipitação pluviométrica no bioma pantanal do Estado do Mato Grosso. Geoambiente On-line, v. 16, p. 01-19, 2011a.

MARCUZZO F.; ROCHA H. M.; MELO D. Mapeamento da precipitação pluviométrica no bioma cerrado do Estado do Mato Grosso. Boletim Goiano de Geografia, v. 31, n. 2, p. 83-97, $2011 b$.

MARCUZZO, F. F.; MELO, D. C.; COSTA, H. C. Sazonalidade e distribuição espaço-temporal das chuvas no bioma do Cerrado do Estado do Mato Grosso do Sul. Revista Brasileira de Recursos Hídricos, v. 17, n. 1, p. 77-86, 2012.

MEllo, C. R.; SÁ, M. A. C.; CURI, N.; MELlO, J. M.; VIOLA, M. R.; da SILVA, A. M. Erosividade mensal e anual da chuva no Estado de Minas Gerais. Pesquisa Agropecuária Brasileira, v. 42, n. 4, p. 537-545, 2007.

MELLO, C. D.; VIOLA, M. R.; BESKOW, S.; NORTON, L. D. Multivariate models for annual rainfall erosivity in Brazil. Geoderma, v. 202, p. 88-102, 2013. https://doi.org/10.1016/j.geoderma.2013.03.009 
MELLO, C. R.; VIOLA, M. R.; OWENS, P. R.; DE MELLO, J. M; BESKOW, S. Interpolation methods for improving the RUSLE R-factor mapping in Brazil. Journal of Soil and $\begin{array}{lllllll}\text { Water Conservation, } & \text { v. } 70, \quad \text { n. 3, p. 182-197, }\end{array}$ http://dx.doi.org/10.2489/jswc.70.3.182

MEUL, M.; VAN MEIRVENNE, M. Kriging soil texture under different types of nonstationarity. Geoderma, v. 112, p. 217-233, 2003. https://doi.org/10.1016/S00167061(02)00308-7

MEUSBURGER, K.; STEEL, A.; PANAGOS, P.; MONTANARELLA, L.; ALEWELL, C. Spatial and temporal variability of rainfall erosivity factor for Switzerland. Hydrology and Earth System Sciences, v. 16, p. 167-177, 2012. https://doi.org/10.5194/hess-16$167-2012$

MONTEBELLER, C. A.; CEDDIA, M. B.; CARVALHO, D. F. de; VIEIRA, S. R.; FRANCO, E. Variabilidade espacial do potencial erosivo das chuvas no Estado do Rio de Janeiro. Engenharia Agrícola, v. 27, n. 2, p. 426-435, 2007. https://doi.org/10.1590/S010069162007000300011.

MORAIS, L. D.; SILVA, V. D; NASCHENVENG, T. D. C.; HARDOIN, P. C.; ALMEIDA, J. D.; WEBER, O. D. S. et al. Índice EI30 e sua relação com o coeficiente de chuva do sudoeste do Mato Grosso. Revista brasileira de ciência do solo, v. 15, n. 3, p. 339-344, 1991.

MOREIRA, M. C.; CECÍLIO, R. A.; PINTO, F. D. A. D. C.; PRUSKI, F. F. Desenvolvimento e análise de uma rede neural artificial para estimativa da erosividade da chuva para o Estado de São Paulo. Revista Brasileira de Ciência do Solo, v. 30, n. 6, p. 1069-1076, 2006.

OLIVEIRA, P. T.; RODRIGUES, D. B.; SOBRINHO, T. A.; CARVALHO, D. F. D.; PANACHUKI, E. Spatial variability of the rainfall erosive potential in the state of Mato Grosso do Sul, Brazil. Engenharia Agrícola, v. 32, n. 1, p. 69-79, 2012. http://dx.doi.org/10.1590/S0100-69162012000100008

OLIVEIRA, P. T. S.; WENDLAND, E.; NEARING, M. A. Rainfall erosivity in Brazil: A review. Catena, v. 100, p. 139-147, 2013. https://doi.org/10.1016/j.catena.2012.08.006

PANAGOS, P.; BORRELLI, P.; MEUSBURGUER, K.; YU, B.; KLIK, A.; LIM, K. J. et al. Global rainfall erosivity assessment based on high-temporal resolution rainfall records. Scientific reports, v. 7, n. 1, p. 4175, 2017.

RENARD, K. G.; FREIMUND, J. R. Using monthly precipitation data to estimate the R-factor in the revised USLE. Journal of hydrology, v. 157, n. 1-4, p. 287-306, 1994. https://doi.org/10.1016/0022-1694(94)90110-4

SILVA, A. M. Rainfall erosivity map for Brazil. Catena, v. 57, n. 3, p. 251-259, 2004. https://doi.org/10.1016/j.catena.2003.11.006

SILVA, S.; de SOUZA, G. S.; de OLIVEIRA, R. B. Variabilidade espacial do potencial erosivo das chuvas para o estado do Espírito Santo, Brasil. Irriga, v. 15, n. 3, p. 312, 2010a. https://doi.org/10.15809/irriga.2010v15n3p312

SILVA, M.; NAVES SILVA, M. L.; CURI, N.; RODRIGUES DOS SANTOS, G. et al. Avaliação e espacialização da erosividade da chuva no vale do rio doce, região centroleste do Estado de Minas Gerais. Revista Brasileira de Ciência do Solo, v. 34, n. 4, 2010 b. 
TRINDADE, A. L. F.; de OLIVEIRA, P. T. S.; ANACHE, J. A. A.; WENDLAND, E. Variabilidade espacial da erosividade das chuvas no Brasil. Pesquisa Agropecuária Brasileira, v. 51, n. 12, p. 1918-1928, 2016.

VIOLA, M. R.; AVANZI, J. C.; de MELLO, C. R.; de OLIVEIRA LIMA, S.; ALVES, M. V. G. Distribuição e potencial erosivo das chuvas no Estado do Tocantins. Pesquisa Agropecuária Brasileira, v. 49, n. 2, p. 125-135, 2014.

WALTRICK, P. C.; de MELlO MACHADO, M. A.; DIECKOW, J.; de OLIVEIRA, D. Estimativa da erosividade de chuvas no estado do Paraná pelo método da pluviometria: atualização com dados de 1986 a 2008. Revista Brasileira de Ciência do Solo, v. 39, n. $1,2015$.

WISCHMEIER, W. H.; SMITH, D. D. Predicting rainfall erosion losses: a guide to conservation planning. Washington: United States Department of Agriculture, 1978. 58p. (Agriculture Handbook, 537).

ZAVATTINi J. A. As chuvas e as massas de ar no estado de Mato Grosso do Sul: estudo geográfico com vista à regionalização climática. São Paulo: Cultura acadêmica, 2009. 